\title{
Mythbusters: Credibilising strategies in popular nutrition books by academics
}

Citation for published version (APA):

Penders, B. (2014). Mythbusters: Credibilising strategies in popular nutrition books by academics. Public Understanding of Science, 23(8), 903-910. https://doi.org/10.1177/0963662513485909

Document status and date:

Published: 01/01/2014

DOI:

10.1177/0963662513485909

Document Version:

Publisher's PDF, also known as Version of record

Document license:

Taverne

Please check the document version of this publication:

- A submitted manuscript is the version of the article upon submission and before peer-review. There can be important differences between the submitted version and the official published version of record.

People interested in the research are advised to contact the author for the final version of the publication, or visit the DOI to the publisher's website.

- The final author version and the galley proof are versions of the publication after peer review.

- The final published version features the final layout of the paper including the volume, issue and page numbers.

Link to publication

\footnotetext{
General rights rights.

- You may freely distribute the URL identifying the publication in the public portal. please follow below link for the End User Agreement:

www.umlib.nl/taverne-license

Take down policy

If you believe that this document breaches copyright please contact us at:

repository@maastrichtuniversity.nl

providing details and we will investigate your claim.
}

Copyright and moral rights for the publications made accessible in the public portal are retained by the authors and/or other copyright owners and it is a condition of accessing publications that users recognise and abide by the legal requirements associated with these

- Users may download and print one copy of any publication from the public portal for the purpose of private study or research.

- You may not further distribute the material or use it for any profit-making activity or commercial gain

If the publication is distributed under the terms of Article $25 \mathrm{fa}$ of the Dutch Copyright Act, indicated by the "Taverne" license above, 


\title{
Mythbusters: Credibilising strategies in popular nutrition books by academics
}

Public Understanding of Science 2014, Vol. 23(8) 903-910

(C) The Author(s) 2013

Reprints and permissions: sagepub.co.uk/journalsPermissions.nav DOI: $10.1177 / 0963662513485909$ pus.sagepub.com

(SAGE

\section{Bart Penders}

Maastricht University, The Netherlands; Harvard University, USA

\begin{abstract}
Healthy eating is a prominent concern amongst public health and diet professionals. Public understanding of healthy eating presents a topic of interest in understanding scientific credibility in the public domain. Three prominent Dutch nutrition scientists, Kok, Seidell and Katan, have produced popular science books on healthy eating, aiming to remove myths about food and nutrition from the public domain. I describe how they do so, and which strategies they have chosen to achieve this goal. In their books, they move beyond traditional academic strategies to build credibility and devise credibilising strategies resembling those of diet authors. While doing so, they move beyond the deficit model, but end up competing for dietary credibility on the diet authors' terms.
\end{abstract}

\section{Keywords}

diet books, nutrition, popular science writing, public credibility of science

\section{Introduction}

Three Dutch nutrition experts have grown frustrated by the perceived errors, mistakes and myths in Dutch public understanding of nutrition, diet and food, especially when related to health- and weight-management. They are Frans Kok, professor of human nutrition at Wageningen University, Jaap Seidell, professor of nutrition and health, and Martijn Katan, emeritus professor of human nutrition, both at the Free University of Amsterdam. They identify the main sources of such untruths or myths to be diet authors who promote diets that will enable (rapid) weight loss without detrimental health effects.

Each professor has recently published a book on nutrition and nutrition science for the Dutch general public: Katan, "What is healthy? Myths and facts about nutrition" (2008); Kok and Scholtens, "Eating healthily, just do it. Proper nutrition according to science" (2011); and Seidell and Halberstadt, "Counterweight - Facts and myths about overweight" (2011). These are the only

\section{Corresponding author:}

Bart Penders, Department of Health, Ethics \& Society, School of Primary Care and Public Health (CAPHRI), Maastricht University, PO Box 616, Maastricht, NL-6200 MD, The Netherlands.

Email: b.penders@maastrichtuniversity.nl 
three popular nutrition science books published by professors over the last four years. Kok explains the raison d'être of his book as "Outrage and wonder about the many diet books that appear" (p. 7); Katan wishes to correct "advice based upon faith or commerce rather than science" (p. 9); Seidell aims to provide a "counterweight to the relentless flow of incorrect, twisted and often misleading information" (p. 12). ${ }^{1}$

Kok, Seidell and Katan are amongst the most prominent contemporary nutritional experts in Dutch nutrition science. Their prominence is, however, not only scholarly. Katan is, amongst other things, a member of the Royal Netherlands Academy of Arts and Sciences, and both Kok and Seidell are members of the Health Council of the Netherlands. Through these positions they influence Dutch policy on healthy eating and lifestyle. Furthermore, all three are active in communicating their own research results and nutrition science in general, to the Dutch. Katan does so most prominently, with regular contributions to Dutch newspapers, radio and television.

In this article I address how public experts such as Kok, Katan and Seidell present their views on healthy eating in their books (in opposition to those of diet authors) and how they aim to construct their views and arguments as credible. ${ }^{2}$ While their writing style surely influences the construction of credibility, this paper will focus on the content and presentation of their claims rather than the aesthetics of credibility. ${ }^{3}$ I first briefly discuss academic convention on building credibility. I then discuss each of the three books and highlight salient elements in the credibilising strategy of each of the three public nutritional experts and finally make an overall assessment of their credibilising strategies. I will argue that the deployment of such strategies demonstrates that these scientists have moved beyond the deficit model, which assumes that a cognitive deficit is responsible for low public understanding and appreciation of (nutrition) science and the public's inability to act upon scientific information. All three professors move beyond the vision that the public's knowledge is deficient whereas science's is sufficient (Gross, 1994). As a result, they find themselves in a continued competition for dietary credibility.

\section{Credibility in science}

In all three books, detailed referrals to published studies are included to convince the audience that the books contain statements that are more credible than others. Such citations are part of the well-known academic credibilising strategy previously described by Latour and Woolgar ([1979] 1986).

Latour and Woolgar demonstrate the work scientists do to make their data, arguments, theories or claims become stable and uncontested truths (i.e. to achieve absolute credibility). The same work enables them to conduct further research by strengthening their reputation and attracting new funding. The process of gathering credibility is never-ending and cyclical: it drives the credit cycle in science, also referred to as the credibility cycle (Hessels and van Lente, 2011; Packer and Webster, 1996). Important in this process are moments of conversion, or translation. Latour and Woolgar show how time, money and effort are translated into data; data are translated into arguments, which are subsequently written down in publications. Peer scientists will read or cite them, resulting in recognition for their claim or argument. This recognition can be mobilised to support new funding requests. The new funding, translated into new personnel, projects or machineries, will produce new data, continuing the cycle. Every translation that takes place contributes to the credibility of a given scientific claim, which extends to the researchers, laboratory or institute making the claim. If the 'scientific wheel of credibility' continues to turn, it will uphold or heighten the credibility of claims and claimants. Academic conventions, such as scientific publications, citations and peer review are part of this credibility cycle. Others have expanded on the cycle through 
the inclusion of patents (Packer and Webster, 1996) or product innovation and consumers (Lehenkari, 2003; Penders and Nelis, 2011).

Popular diet authors promise solutions to weight- or health-related problems. Their credibility strategy relies on the use of cases, employing characters people can relate to, allowing for a "metaphorical extension" on to oneself (Shapin, 2007: 186). In addition, they are explicit about their own struggles with food and weight. They explicate sets of norms and values, and aim at an audience that shares them (Kahan, 2010). There is science in their stories, but either it is positioned as an alternative to the dominant scientific infrastructure in an active disavowal of formal expertise, as, for example, popular diet authors Dr. Atkins and Dr. Agaston do in their books (Shapin, 2007), or it is actively pushed into the background, as Sonja Bakker does in her books (Penders, 2012).

Seidell's, Katan's and Kok's claims about nutrition are not, by default, credible. The credibility cycle as a strategy to construct credibility is powerful only within the scientific community: outside the university walls, peer review and citation cultures are relatively unknown and cannot accrue similar credibility (Brown, 2004; Scott, 2011). Perry et al. (2007) argue that if science does not work anymore, or is unable to create an advantage, professionals seek out new trajectories and may "exploit personal identities and embodied subjectivities as additional sources of authenticity and credibility" (p. 26). Each of the three authors discussed below has opted for his own style of exploiting such additional sources.

\section{3. “Eating healthily, just do it"}

Before moving into "Proper nutrition according to science", the book's subtitle, Kok and Scholtens first devote a chapter to positioning Dr. Atkins, Sonja Bakker and Dr. Frank and their diets as nonfunctional, unscientific and (sometimes) dangerous. Bold formulations, such as "Diet gurus wish to make us believe that their diets really work and live up to the standards of nutrition science" ( $p$. 9) suggest that they evaluate diet authors as deceptive. Kok argues that "Atkins" works for a short period of time only and is not effective with sustained use; "Dr. Frank" makes people eat dangerously little, including too few carbohydrates; and Sonja Bakker's diet prescribes extremely few calories (p. 12).

To Kok, dietary advice is part of general lifestyle advice and physiology. His book juxtaposes discussions of measurements of the body, genetics, movement and sports with illustrations of wheels and cogs (p. 34) and measuring tapes (p. 19). He conveys the message that insight into what is health(y) is not very complicated and because it is so simple, one should "just do it": "Healthy eating does not have to be complicated. It does not involve strict or complicated dietary regimes as many diets do [...]. Choose the right products in the right combinations and amounts [...]. This should become a daily routine". Nevertheless, characteristics of our present society that stand in the way of 'just doing it' are not ignored. Kok describes the obesogenic society as a series of hurdles one ought to overcome. Those hurdles consist partly of a lack of knowledge, but for the most part a lack of self-control and an irresponsible supply of unhealthy, high-caloric foods.

Through self-experimentation, Kok demonstrates that these hurdles can be overcome. He reports how eating more and moving less made him less healthy and heavier; returning to a healthier lifestyle made him lose the weight again. The 'case of the author' is a genre which is (almost) lost from scientific literature, a remnant from early modern medical literature (Shapin, 2007). Outside scientific literature, however, it is very much alive. Celebrities like Oprah Winfrey have written books on dieting and weight loss (Greene and Winfrey, 1996). Authors opt for such a style to align themselves with their reader (Kahan, 2010; van Rijswoud, 2012), and suggest that they are like the reader and found sticking to a diet hard (Shapin, 2007). 
Upon closer inspection, Kok's eating experiment appears to pursue a different goal. In the chapter in which he reports his self-experimentation, he uses the passive voice, contrary to all the other chapters: "There was no running" and "The body reacted according to the principles of nutritional lore". Instead of pursuing overlap between author and reader, Kok creates distance. Unlike the reader, he needs to restrain himself from running. Using the metaphorical voice from nowhere, he comments upon the situation from afar. He demonstrates that it does not cost him any effort to live healthily and to gain and lose weight, thereby estranging the reader who may have experienced this as unattainable all her life.

Kok's eating experiment symbolises the book's relationship to its audience: 'I'll demonstrate it and now it is up to you'. This is strengthened by the inclusion of recipes at the end of the book, which he used himself during this experiment: "These recipes adhere to the principles of the food pyramid and fit the criteria of the Dutch Nutritional Centre" (p. 117). However, Kok is not like the people he addresses. He is slender, physically active, highly educated, knowledgeable about food and nutrition, successful and he earns well. Instead of 'I am like you', he suggests 'You ought to be like me' and 'My body (and my recipes) is the standard for all'. Kok's credibilising strategy is positive, enabling and individual, but it is also sometimes highly moralising.

\section{4. “Counterweight"}

Seidell's “Counterweight” limits itself to overweight and obesity. Seidell takes a partially autobiographical approach, describing how his entire professional life has been centred on the study of, and fight against, obesity. He recalls that as a student he met (morbidly) obese people who got useless tips on losing weight and counting calories. Ten years later, and a prominent obesity researcher, he learned that the Dutch obesity association perceived him as their worst enemy: he contributed to the negative image of fat people. Through such personal stories, Seidell demonstrates how he learned the hard way that science is relative: more knowledge is not enough. Consequentially, his book takes both the scientific and the societal perspectives seriously. He extends his story to include, next to the (obese) individual, sectors such as education and public health care (p. 12).

While reading, we learn about Seidell. His analysis of the difficulty of pinning down the causes of the obesity epidemic shows the breadth of issues he is willing to consider. He ultimately concludes that it is absurd to view obesity or 'overweight' as the result of personal choices for which individuals are to be held responsible.

His book is filled with facts about obesity, mostly wrapped into anecdotes starring famous nutritional scientists. Sometimes this takes the explicit form of hero worship (e.g. the exposé on Mickey Stunkard, p. 172), but usually it resembles the following: "In the middle of the eighties, I collaborated with the Swedish internist Per Björntorp. [...] Björntorp was one of these rare visionaries in obesity research" (p. 37). Through such rhetoric, Seidell establishes authority for these experts and by stressing their collaboration also for himself (Maienschein, 1993).

Seidell documents personal interaction with obese people, patient organisation representatives and a variety of scientific and cultural practices and translates these into critical but very accessible observations of the 'obesogenic society': "Pig farmers have known for a very long time that temperature is important for our metabolism. They keep their barns warm, because they know it makes their pigs fat. Our [...] modern homes are no different" (p. 60).

Like Kok, he also experimented with his own body: "I have also tried to lose a lot of weight. After reading so much scientific literature about weight regulation I grew curious about what happens when you lose weight. I succeeded in losing about 15 per cent of my body weight, but I cannot 
remember a period that was so miserable" (p. 79). Contrary to Kok, Seidell mentions how he felt: really bad.

Seidell includes a historical and sociological account of the policy approaches designed to deal with the obesity epidemic. This way, he demonstrates the complexity of the obesity epidemic. In all this complexity, there are always those who take advantage of the situation. Seidell narrates how he was invited to speak at a conference, to explain the difficulties of understanding obesity. His talk was followed by pharma-reps attempting to sell anti-obesity pills. After a while he realised that his expertise and reputation were being exploited for marketing purposes. Similar to Kok who criticises diet authors, Seidell takes issue with the weight loss industry: "The diet industry sells, just like astrologers and alternative medicine, hope to desperate people struggling all their life with a chronic illness like obesity" (p. 147). Diet authors feature in his book as well, though only in the context of weight loss. Seidell is himself at the heart of his story. He is an expert amongst other experts, but with an open eye to personal experience: his and others'.

\section{5. “What is healthy?"}

Katan starts his book by devoting a chapter to the practice and the role of science. He includes a discussion on how science is organised, how facts emerge and travel, and the amount of work scientists do to unearth links between nutrition and health. Katan does not eschew the contested nature of research and also discusses why food scientists disagree with one another: "Even scientific research can be the source of unproven convictions about food and health" and he readily dives into the topic of the food industry's influence on nutrition science. As a result, he cannot refrain from disclosing his own relationships (p. 21). But Katan does not limit himself to explaining how science works - he also explores the relationship between science and society. He accepts general concerns about science and technology in society, and acknowledges that food is not exempt from them. He acknowledges that personal opinions may exist in stark contrast to scientific facts and that the former may easily outweigh the latter. He finishes his first chapter with a disclaimer: "Statements about nutrition and health are often based on convictions or interests, 'scientifically studied' is no guarantee for quality or correctness [and] science has no answer to many questions" (p. 23).

Katan displays humility when it comes to his discipline's authority: "Ask someone what healthy food is and 99 out of a 100 people answer firmly. The one, who isn't sure, is a nutrition scientist" (p. 13). Through such statements, Katan forwards reflexivity and a critical stance about science and the expertise it can offer. Katan writes that "the reader I envision is not only prepared to do something for his [sic] own health or that of the people close to him [sic], but is also interested in science and is not gullible" (p. 9). Later, he adds "On average, the Dutch would live longer [...] if they were to eat differently. For those average Dutch, this book was written" (p. 32), only to add a caveat to this universality: "Ask yourself with every advice in this book whether it applies to you and how far you can go before healthy becomes unhealthy" (p. 33). While he writes for the average Dutchman, he expects an above-average interest in science. Making Katan's universal claims and advice particular (or personal) is an individual responsibility and Katan and the science he introduces often do not offer concrete clues. Following a 5-page discussion of breakfast and bread, the question 'what should I put on my bread?' is answered as follows: "That doesn't matter a lot, as long as you do not spread your sandwich too thick. Especially with cheese and peanut butter, calories quickly add up" (p. 43).

Katan's book is supported by 413 notes and followed by guidelines on how to find additional information about healthy food yourself. Besides presenting information about food, Katan also 
wishes to enable people to gather credible information themselves, and judge claims about nutrition: "This book will probably not have answered all your questions about healthy and less healthy foods. You may want to check what other experts have to say" (p. 181). He includes a crash course in media coverage, label reading and logo interpreting and challenges people to critically evaluate seemingly simple claims such as expiration dates. Katan's credibilising strategy is characterised by the attention devoted to how science works and the instilling of critical capacity in consumers.

\section{Discussion}

Literature on healthy nutrition has become populated with non- or semi-scientific diet authors. Scientists have responded with scientific popular books on food and nutrition. The three books discussed here display little sympathy for diet authors, their diets and their claims to credibility. It is therefore surprising that, albeit in varying degrees, they wield strategies of establishing credibility resembling those of diet authors.

Kok includes the prominent account of an experiment with his own body, weight and health and presents the message that living healthily is both possible and achievable. The 'packaging' is very popular as well, with recipes, full-colour illustrations and a square format. Kok clearly does not want to be a diet 'guru', but the presentation of his message arguably begs to differ. Seidell's book looks more traditional and is written in a different style. Although by no means autobiographical, Seidell's book opens up a number of windows on to his personal and professional life. His book is about a very specific subset of food science, namely the science that he did, liked and was dazzled by. His (light) autobiographical stories enable an alignment between Seidell as an expert and a lay audience sharing similar norms and values (Kahan, 2010). Katan starts his account as an amateur sociologist of science, although he does not refer to any sociological literature. He explains how science works, why scientists do not always agree with one another and which parts of science are happening backstage, and which parts are out for all to see. He leaves open room for manoeuvre, allowing readers to deal with the heterogeneity of science.

Kok, Seidell and Katan dismiss diet books and diet authors to varying degrees, but their books draw from the very same (personal) narrative tactics, discursive structures and concrete lifestyle messages - the same credibilising strategies - that these authors use. Other ingredients of the diet authors' strategies, including de-emphasising science and personal engagement are absent from Kok, Seidell and Katan's books. They remain distant scientists, despite their best efforts. Kok distances himself too much from his account to enable his narrative to resemble that of a diet author. Seidell's biography is too much an account of his professional life, and too little an account of the life of an 'eating individual' to enable a full display of values to allow a public to identify with them. Katan opens as a sociologist of science, but retreats into a positivistic position when it comes to descriptions of the relationship between diet and health. The heterogeneity he admits to characterise all science is notably absent from his account. In the end, science is about the truth, and there is only one of those. ${ }^{4}$

Van Rijswoud (2012) and Wynne (1992) argue that experts carefully cater to their clientele, considering that trust and credibility are relational notions and say nothing about the content of a claim. Kok, Seidell and Katan actively cater to their clientele, and in order to do so, they adopt credibilising strategies resembling those of the diet authors they dismiss. This testifies to their awareness that mere dissemination does not suffice - they have moved beyond the deficit model. Yes, they provide scientifically sound dietary knowledge, but above all else they aim to actively convince and build credibility for that knowledge, through stories or otherwise. They continue to be scientists, assuming that their readers share a very specific world view in which in all things 
nutritional, science has a preferred access to reality. For this reason, they carefully maintain the boundaries between science and pseudoscience (labelled 'myths' or 'diet gurus' in these books), assuming a higher credibility for all things scientific (Gieryn, 1999).

This extends into a 'credibility problem' for all three books. Kok, Seidell and Katan seem to assume that their books and arguments will be more credible than those of others. Like Discovery Channel's Mythbusters, who debunk a myth and replace it by a fact, they suggest that public doubt and nutritional scientific heterogeneity are exchanged for clarity, certainty and homogeneity. Kok, Seidell and Katan set out to debunk myth and to promote fact, to 'solve' the problem of heterogeneity in science. However, these three books are not disrupting the status quo of credibility distribution in the dietary marketplace. Kok, Seidell and Katan wield similar credibilising strategies to the (more famous) diet authors. The ironic result is that they are now competing for dietary credibility on the diet authors' terms.

\section{Acknowledgements}

I thank Frans van Dam, Inge Lecluijze, Erwin van Rijswoud, David Townend and the PUS reviewers, who helped improve this analysis.

\section{Funding}

This research was supported by CSG Centre for Society and the Life Sciences, the Netherlands.

\section{Notes}

1. Titles and quotes have been translated from Dutch by the author.

2. I offer brief background data on all three books and a description of their selection and analysis in the accompanying online supplementary material [See Online Appendix].

3. The aesthetics of credibility are understudied in PUS and STS. Webpage design and webpage credibility offer an interesting starting point, blending aesthetics and content.

4. Interestingly, one of Katan's famous statements about food and health is the claim that a Dutch '(ragout) croquette-bun' is healthier than a Dutch 'cheese-bun'. This claim is subsequently labelled as a myth by Frans Kok in his book, and dismissed accordingly (p. 55).

\section{References}

Brown T (2004) Stop whispering about peer review. The Scientist 18(17): 8-9.

Gieryn TF (1999) Cultural Boundaries of Science: Credibility on the Line. Chicago: University of Chicago Press.

Greene B and Winfrey O (1996) Make the Connection: Ten Steps to a Better Body and a Better Life. New York: Hyperion.

Gross AG (1994) The roles of rhetoric in the public understanding of science. Public Understanding of Science 3(1): 3-23.

Hessels L and van Lente H (2011) Practical applications as a source of credibility: A comparison of three fields of Dutch academic chemistry. Minerva 49: 215-240.

Kahan D (2010) Fixing the communications failure. Nature 463: 296-297.

Katan MB (2008) Wat is nu gezond? Fabels en feiten over voeding. Amsterdam: Bert Bakker.

Kok FJ and Scholtens B (2011) Gezond eten, gewoon doen. Goede voeding volgens de wetenschap. Amsterdam: Bert Bakker.

Latour B and Woolgar S ([1979] 1986) Laboratory Life: The Construction of Scientific Facts. Princeton: Princeton University Press.

Lehenkari J (2003) On the borderline of food and drug: Constructing credibility and markets for a functional food product. Science as Culture 12(4): 499-525. 
Maienschein J (1993) Why collaborate? Journal of the History of Biology 26(2): 167-183.

Packer K and Webster A (1996) Patenting culture in science: Reinventing the scientific wheel of credibility. Science, Technology and Human Values 21: 427-453.

Penders B (2012) De mensen hebben een gezicht nodig [An interview with Sonja Bakker]. In: Penders B and Van Dam F (eds) Ingrediënten van Geloofwaardigheid. Goed Eten onder de Loep. Den Haag: Boom Lemma, pp. 42-46.

Penders B and Nelis AP (2011) Credibility engineering in the food industry: Linking science, regulation and marketing in a corporate context. Science in Context 29(4): 487-515.

Perry EM, Mata JM and Gieryn TM (2007) Science and the discursive politics of policy: Examining credibility and policy framing. Paper presented at the Annual Meeting of the American Sociological Association.

Scott J (2011) Evidence to House of Commons Science and Technology Committee. Peer review in scientific publications: Eighth Report of Session 2010-12. HC 856. London: The Stationery Office, pp. Ev w44-46.

Seidell JC and Halberstadt J (2011) Tegenwicht. Feiten en fabels over overgewicht. Amsterdam: Bert Bakker. Shapin S (2007) Expertise, common sense and the Atkins diet. In: Porter JM and Phillips PWB (eds) Public Science in Liberal Democracy. Toronto: University of Toronto Press, pp. 174-193.

van Rijswoud E (2012) Public faces of science: Experts and identity work in the boundary zone of science, policy and public debate. PhD Thesis, Radboud University of Nijmegen, Nijmegen.

Wynne B (1992) Misunderstood misunderstandings: Social identities and the public uptake of science. Public Understanding of Science 1: 281-304.

\section{Author biography}

Bart Penders is an Assistant Professor in Biomedicine and Society, currently researching and teaching at Maastricht University, the Netherlands. In 2013 and 2014 he is also an Edmond J. Safra Network Fellow at Harvard University. His research deals with scientific collaboration in biomedicine and nutrition science. He studies how scientists collaborate to create knowledge, how they render such knowledge credible and how non-scientists are involved in knowledge production and credibilisation. 